Şeker, Z. C. (2020). Ana Dili Eğitimi Dergisi'nde yayınlanan makalelerin anahtar kelimeleri üzerine betimsel bir analiz. Ana Dili Eğitimi Dergisi, 8(3), 797-811.

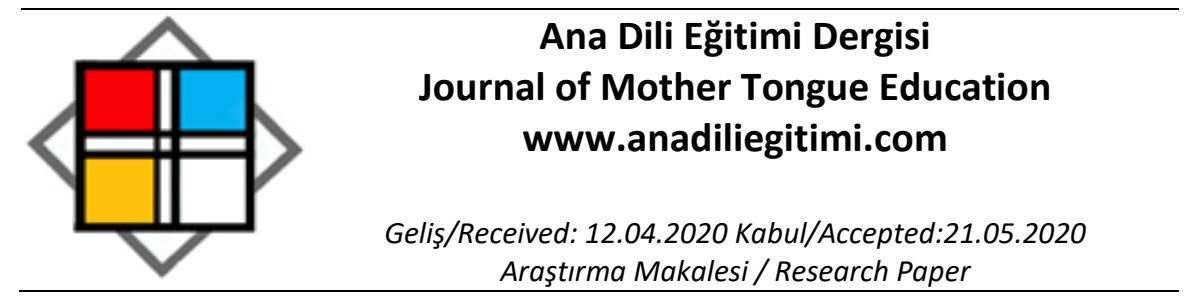

\title{
Ana Dili Eğitimi Dergisi’nde Yayınlanan Makalelerin Anahtar Kelimeleri Üzerine Betimsel Bir Analiz
}

\author{
Zeynep CIN ŞEKER*
}

\begin{abstract}
Öz
Bu çalışmada Türkçe eğitimi alanında yayımlanan ilk bilimsel dergi olma özelliği gösteren Ana Dili Eğitimi Dergisi'nde 2013-2020 yılları arasında yayınlanan 335 makalenin anahtar kelimeleri betimsel olarak analiz edilmiştir. Araştırmada nitel temel desen tercih edilmiştir. Veriler doküman incelemesi ile toplamış ve betimsel analizle incelenmiştir. Illk olarak makalelerde kullanılan anahtar kelimeler tespit edilmiş ve bu kelimeler belirlenen temalar altında frekans değerleri ile birlikte sunulmuştur. Araştırmada elde edilen sonuçlara göre en çok kullanılan anahtar kelimelerin Türkçe eğitimi/yabancılara Türkçe öğretimi/dil öğretimi konu alanları ile ilgili olduğu görülmüştür. Temel dil becerileri ile ilgili anahtar kelimelerin okuma ve yazma becerilerinde yoğunlaştığı, dinleme ve konuşma becerisine yönelik kelimelerin ise az olduğu belirlenmiştir. Makalelerde, metin/metin çözümleme ve dil bilgisi/dilbilim ile ilgili anahtar kelimelerin de sık kullanıldığı tespit edilmiştir. Söz varlığı, öğretmen/öğretmen adayı/öğrenci/ebeveyn, drama/tiyatro, değer, çocuk edebiyatı alanlarına yönelik anahtar kelimelerin ise diğer temalara oranla daha sınırlı olduğu sonucuna ulaşılmıştır.
\end{abstract}

Anahtar Kelimeler: Ana Dili Eğitimi Dergisi, anahtar kelime, Türkçe eğitimi

\section{A Descriptive Analysis on the Keywords of Articles Published in the Journal of Mother Tongue Education}

\begin{abstract}
In this study, the keywords of 335 articles published between 2013 and 2020 in the Journal of Mother Tongue Education, which is the first scientific journal published in the field of Turkish language education, were analyzed descriptively. The qualitative basic pattern was preferred in the study. The data were collected by document analysis and analyzed by descriptive analysis. At first, the keywords used in the articles were identified and these words were presented together with the frequency values under the themes determined. According to the results obtained in the study, it was observed that the most frequently used keywords were related to the subject fields of Turkish language education/Teaching Turkish language to foreigners/language teaching. It was determined that the keywords related to basic language skills were concentrated in reading and writing skills, and the words for listening and speaking skills were few in number. In the articles, it was determined that the keywords related to text/text analysis and grammar/linguistics were also frequently used. It was concluded that the keywords related to the fields of vocabulary, teacher/pre-service teacher/student/parent, drama/theater, value, children's literature are fewer than other themes.
\end{abstract}

Keywords: Journal of Mother Tongue Education, keyword, Turkish language education

\section{Giriş}

Türkçe eğitimi alanının lisansüstü programlarında son yıllarda bir artış olduğu görülmektedir. Bu artış Türkçe eğitimi alanındaki akademik çalışmalara eğilimi artırmıştır. Dolayısıyla Türkçe eğitimi-

\footnotetext{
${ }^{*}$ Dr. Ögr. Üyesi, Atatürk Üniversitesi, Kâzım Karabekir Eğitim Fakültesi, Türkçe ve Sosyal Alanlar Eğitimi Bölümü, Türkçe Eğitimi Ana Bilim Dalı, zeynep.seker@atauni.edu.tr, ORCID: 0000-0002-0294-2961
} 
öğretimi alanında çalışma yapan araştırmacılar için yayınlanan makale, tez gibi bilimsel yayınların hangi alt konularda yoğunlaştığını takip etmek önem kazanmıştır.

Alan yazın taraması yapan araştırmacılar ilk aşamada, taradıkları çalışmaların belirli bölümlerini okuyarak kendi araştırmaları ile ilgili olup olmadığına karar verirler. Taranan çalışmaların içeriği ile ilgili bilgi veren bölümlerden biri ise anahtar kelimelerdir. Dilidüzgün $(2017$, s. 78 ) anahtar kelimeleri ve anahtar kelimelerin metin oluşturma ve metni anlama aşamasındaki önemini "Anahtar sözcükler, metnin temel içeriğiyle ilgili bilgi vermektedirler. Metnin iskeletini kuran bu sözcükler büyük ölçekli önermelerde ve özet metinlerin içeriğinde bulunması gereken sözcüklerdir. Metnin anahtar sözcüklerinin saptanması metnin bütünüyle anlaşıımasını gerektirir." şeklinde açıklamıştır. Metinde sıkça geçen kelimeler metnin konusu hakkında okuyucuya bilgi verir. Akademik metinlerde ise anahtar kelimeler hem çalışmanın konu alanını ortaya çıkarma hem de alandaki araştırmacıların çalışmaya ulaşmasını kolaylaştırma açısından önem taşır. "Alan yazındaki bilimsel içerikli yayınların anahtar kelimelerinin tespiti, gidişatın hangi yöne doğru olduğunu; hangi konuların daha çok çalışılıp hangilerinin daha az çalışıldığı, alan yazındaki yeniliklerin neler olabileceği konularında bilgi verdiği gibi gelecekle ilgili etkili yönlendirmelerin yapılabilmesine de ortam hazırlar." (Sevim ve işcan, 2012, s. 1864). Bu bağlamda Türkçe eğitimi ile ilgili makalelerde yer alan anahtar kelimelerin bu alanda çalışan araştırmacılara yol gösterici nitelikte olacağı düşünülmektedir.

Alan yazında, Türkçe eğitimi ve öğretimi ile ilgili bilimsel çalışmaların anahtar kelimeleri üzerine değerlendirme sunan araştırmalara rastlanmaktadır (Sevim ve İşcan, 2012; Erdem, Gün, Şengül ve Özkan, 2015). Türkçe eğitimine yönelik bilimsel makalelerin, yüksek lisans ve doktora tezlerinin eğilimlerini inceleyen araştırmalar da bulunmaktadır. Bunlar genel olarak Türkçe eğitimi ve öğretimi, Yabancılara Türkçe öğretimi alanında yapılan yüksek lisans ve doktora tezlerini, bildiri ve makale çalışmalarını kapsamaktadır (Varışoğlu, Şahin ve Göktaş, 2013; Yağmur-Şahin, Kana ve Varışoğlu, 2013; Büyükikiz, 2014; Bozkurt ve Uzun, 2015; Aktaş ve Uzuner Yurt, 2015; Boyacı ve Demirkol,2018; Şeref ve Karagöz, 2019). Bunun yanında alan yazında, temel dil becerilerine yönelik bilimsel çalışmaların eğilimlerini ortaya koyan araştırmalar da yer almaktadır (Elbir ve Yıldız, 2012; Balcı, Coşkun ve Özçakmak, 2013; Coşkun, Balcı ve Özçakmak, 2013; Doğan ve Özçakmak, 2014; Karadağ, 2014; Tok ve Potur, 2015; Akaydın ve Çeçen, 2015; Uyar, 2016; Kemiksiz, 2017; Alver ve Taşdemir, 2017; Ceren, Aydın ve Onarıcıoğlu, 2018; Özdemir, 2018; Kardaş, Çetinkaya ve Kaya, 2018; Karagöz ve Şeref, 2019a; Karagöz ve Şeref, 2020). Bu çalışmada ele alınan Ana Dili Eğitimi Dergisi'nde yer alan makaleler üzerine inceleme yapan çalışmalar da bulunmaktadır (Mutlu, 2018; Karagöz ve Koç Ardıç, 2019). Mutlu (2018) Ana Dili Eğitimi Dergisi'nde yayınlanan 207 makaleyi Türkçe eğitimi ve eğitim bilimleri konu alanı, yöntemi, veri toplama araçları, veri analiz yöntemleri, örneklem yöntemi, büyüklüğü ve düzeylerine göre analiz etmiştir. Karagöz ve Koç Ardıç (2019) ise 2013-2018 yılları arasında Ana Dili Eğitimi Dergisi'nde yayınlanan makaleleri "makale sayısı, makalelerin yayın dili, makalelerin sayfa sayıları, makalelerin yazarlık durumları, yazarların çalıştıkları kurumlar, yazarların unvanı, makalelerin değerlendirme süresi, makalelerdeki kaynak türleri, makalelerdeki kaynakça sayılarının dağıımı, makalelerin konu dağılımı" açııından bibliyometrik yaklaşımla incelemişlerdir.

Alan yazın incelendiğinde Ana Dili Eğitimi Dergisi'nde yayınlanan makalelerin anahtar kelimeleri üzerine bir çalışma yapılmadığı görülmüştür. Bu bağlamda ULAKBiM TR Dizin'de taranan Ana Dili Eğitimi Dergisi'nde yer alan makalelerin anahtar kelimeleri üzerine bir değerlendirme yapmak amaçlanmıştır. Çalışmada Ana Dili Eğitimi Dergisi'nin seçilme nedeni ise derginin "Türkçe eğitimi alanında yayımlanan ilk ve tek bilimsel dergi" (Karagöz ve Koç Ardıç, 2018) olmasıdır. Bu açıdan bakıldığında dergide yer alan makalelerin anahtar kelimelerinin ve anahtar kelimelerinden hareketle konu eğilimlerinin belirlenmesi Türkçe eğitimi alanında çalışan araştırmacılar için yol gösterici olacaktır. Dergide yer alan makalelerin anahtar kelimeleri Türkçe eğitimi ve öğretimi bağlamında incelenmiş ve belirlenen temalara göre frekans değerleri tablo biçiminde sunulmuştur.

\section{Araştırmanın Modeli}

\section{Yöntem}

Çalışmada nitel temel desen kullanılmıştır. Bütün nitel araştırmalar anlamın nasıl inşa edildiğiyle, insanların hayatlarını ve dünyalarını nasıl anlamlandırdıklarıyla ilgilidir. Nitel temel desenin 
öncelikli amacı bu anlamları açığa çıkarmak ve yorumlamaktır (Merriam, 2013, 24). Araştırmada, Ana Dili Eğitimi Dergisi'nde yayınlanan makalelerde kullanılan anahtar kelimelerin Türkçe eğitimi konu alanlarına göre derinlemesine betimlenmesi amaçlandığı için nitel desen tercih edilmiştir.

\section{Verilerin Toplanması}

Araştırmanın verileri doküman incelemesi ile toplanmıştır. Doküman incelemesi, araştırılması hedeflenen olgu veya olgular hakkında bilgi içeren yazılı materyallerin analizini kapsar (Yıldırım ve Şimşek, 2008). Araştırma kapsamında Ana Dili Eğitimi Dergisi'nde 2013-2020 yılları arasında yayınlanan 335 makale taranmış ve makalelerde kullanılan anahtar kelimeler tespit edilmiştir. Araştırma sürecinde 2020 yılında sadece 1. Sayı yayınladığı için bu sayıdaki makaleler incelenmiştir. Çalışmada incelenen makalelerin yıllara göre dağııımı Tablo 1'de belirtilmiştir.

Tablo 1.

Ana Dili Eğitimi Dergisi'nde Yayınlanan Makalelerin Yıllara Göre Dağılımı

\begin{tabular}{ll}
\hline YIl & Makale Sayısı \\
\hline 2013 & 32 \\
2014 & 30 \\
2015 & 25 \\
2016 & 41 \\
2017 & 58 \\
2018 & 68 \\
2019 & 66 \\
2020 & 15 \\
\hline Toplam & 335 \\
\hline
\end{tabular}

\section{Verilerin Analizi}

Doküman incelemesi tekniğiyle toplanan veriler, betimsel analiz ile çözümlenmiştir. Betimsel analiz, elde edilen verilerin daha önceden belirlenen temalara göre özetlenip yorumlanmasıdır. Bu tür analizde amaç elde edilen bulguları düzenlenmiş ve yorumlanmış bir biçimde okuyucuya sunmaktır. Bu amaçla elde edilen veriler, önce sistematik ve açık bir biçimde betimlenir. Daha sonra yapılan bu betimlemeler açıklanır ve yorumlanır, neden-sonuç ilişkileri irdelenir ve birtakım sonuçlara ulaşılır. Betimsel analiz dört aşamadan oluşur:

1. Betimsel analiz için bir çerçeve oluşturma

2. Tematik çerçeveye göre verilerin işlenmesi

3. Bulguların tanımlanması

4. Bulguların yorumlanması (Yıldırım ve Şimşek, 2008, s. 224).

Çalışmada öncelikle anahtar kelimeler tespit edilmiştir. Daha sonra anahtar kelimeler, Türkçe eğitimi alanı ile ilişkili alt temalara göre tasnif edilmiş ve frekans değerleri belirlenmiştir. Birbirine benzer anahtar kelimeler birlikte ele alınmış ve frekans değerleri birleştirilmiştir. Belirlenen temaların dışında kalan ve Türkçe eğitimi-öğretimi/yabancılara Türkçe öğretimi/ dil öğretimi temasında frekans değeri 1 olan anahtar kelimeler ise ek dosya olarak makale ekinde sunulmuştur.

\section{İnandırıcılık ve Aktarılabilirlik}

Araştırmanın inandırıcılık ve aktrılabilirliğini sağlamak amacıyla araştırmacı tarafından tespit edilip içerik analizi yöntemi ile tasnif edilen anahtar kelimeler, bir alan uzmanının görüşüne sunulmuştur. Alan uzmanının görüşleri doğrultusunda bazı anahtar kelimeler belirlenen temalara eklenmiştir. Anahtar kelimelerin içerik analizinde araştırmacı ile alan uzmanının ortak görüşü dikkate alınmıştır. 


\section{Bulgular}

Bu bölümde Ana Dili Eğitimi dergisinde yayınlanan 335 makaleden elde edilen anahtar kelimelerin konu alanlarına göre dağılımına ve frekans değerlerine yer verilmiştir.

Okuma becerisine ile ilişkili anahtar kelimelere Tablo 2'de yer verilmiştir.

Tablo 2.

Okuma Becerisine Ilişskin Anahtar Kelimeler

\begin{tabular}{|c|c|c|c|c|c|}
\hline Sira & Anahtar kelimeler & $f$ & Sira & Anahtar kelimeler & $\mathrm{f}$ \\
\hline 1. & Okuma & 13 & 25. & Çok katmanlı okuryazarlık & 1 \\
\hline 2. & Okuduğunu anlama & 5 & 26. & Erken okuryazarlık becerileri & 1 \\
\hline 3. & $\begin{array}{l}\text { Illk okuma yazma öğretimi/ilk okuma } \\
\text { yazma }\end{array}$ & 5 & 27. & Kitap okuma & 1 \\
\hline 4. & Akıcı okuma & 4 & 28. & Şiir okuma & 1 \\
\hline 5. & Okuma kültürü & 3 & 29. & Kitap okuma motivasyonu & 1 \\
\hline 6. & Okuma tutumu & 3 & 30 & Okuma etkinlikleri & 1 \\
\hline 7. & Okunabilirlik & 2 & 31. & Okuma bozukluğu & 1 \\
\hline 8. & Okuma becerisi & 2 & 32. & Anlam kurma & 1 \\
\hline 9. & Okuma kazanımları & 2 & 33. & Anlama güçlüğü & 1 \\
\hline 10. & Etkileşimli okuma & 2 & 34. & Okuma güçlüğü & 1 \\
\hline 11. & Okuma eğitimi & 2 & 35. & Disleksi & 1 \\
\hline 12. & Okuma alışkanlığı & 2 & 36. & Anlama & 1 \\
\hline 13. & Okuma çemberleri & 2 & 37. & Okuma metni & 2 \\
\hline 14. & Okuduğunu anlama becerisi & 2 & 38. & Görsel okuma & 1 \\
\hline 15. & Okuma motivasyonu & 2 & 39. & Okuma becerileri & 1 \\
\hline 16. & Okuma yazma öğretimi & 2 & 40. & Bilişsel okuma stratejileri & 1 \\
\hline 17. & Ekran okuma & 2 & 41. & Okuma sevgisi ve isteği & 1 \\
\hline 18. & Görsel okuryazarlık & 2 & 42. & PISA okuma becerileri & 1 \\
\hline 19. & Bilgi okuryazarlığı & 2 & 43. & Şiir okuma performansı & 1 \\
\hline 20. & Okuryazarlık & 2 & 44. & Bilişsel okuma stratejileri & 1 \\
\hline 21. & Dijital okuryazarlık & 1 & 45. & İçerik okuma & 1 \\
\hline 22. & Okumaya ilişkin tezler & 1 & 46. & Okuma araştırmalarında eğilimler & 1 \\
\hline 23. & Eleştirel okuryazarlık & 1 & 47. & Anlama stratejileri & 1 \\
\hline 24. & Kitap seçim ölçütleri & 1 & 48. & Hikâye kitapları & 1 \\
\hline
\end{tabular}

Okuma becerisine ilişkin 49 farklı anahtar kelime tespit edilmiştir. Tablo 2 incelendiğinde okuma becerisine yönelik anahtar kelimelerin 'okuma', 'okuduğunu anlama', 'ilk okuma yazma' ve 'akıcı okuma' gibi temel konular üzerinde yoğunlaştığı görülmektedir.

Yazma becerisine yönelik anahtar kelimelerin frekans değerleri Tablo 3'te sunulmuştur.

Tablo 3.

Yazma Becerisine Iliş̧kin Anahtar Kelimeler

\begin{tabular}{|c|c|c|c|c|c|}
\hline Sira & Anahtar kelimeler & $f$ & Sira & Anahtar kelimeler & $f$ \\
\hline 1. & Yazma & 12 & 21. & Yazma süreci & 1 \\
\hline 2. & Yazma becerisi & 12 & 22. & Yazma becerileri & 1 \\
\hline 3. & Yazma eğitimi & 11 & 23. & Not alma stilleri & 1 \\
\hline 4. & Yazılı anlatım & 5 & 24. & Yansıtıcı günlük yazma & 1 \\
\hline 5. & Yaratıcı yazma & 4 & 25. & Yaratıcı yazarlık becerisi & 1 \\
\hline 6. & Akademik yazma & 3 & 26. & Öykü yazma becerisi & 1 \\
\hline 7. & Yazma kaygısı & 2 & 27. & Yazılı iletişim & 1 \\
\hline 8. & Yazma öğretimi & 2 & 28. & Yazma tutumu & 1 \\
\hline 9. & Not alma & 2 & 29. & Yazım yanlışı & 1 \\
\hline
\end{tabular}


10. Yazma eğilimi/eğilimleri

11. Bitişik eğik yazı

12. Dik temel yazı

13. Süreç temelli yazma öğretimi/yaklaşımı

14. Ürün temelli yazma öğretimi

15. Yazmaya yönelik tutum

16. Şiir yazma

17. Şiir yazmaya yönelik tutum

18. Akran destekli yazma

19. Yazı farkındalığı

20 Yazma başarı ve performansı
30 Yazma düzeyi 1

31. Hikâye yazma 1

32. Yazma tercihi 1

33. Yazı eğitimi 1

34. Yazı okunaklığı 1

35. Yazma alışkanlığı 1

36. Analitik yazma ve değerlendirme 1 modeli

37. $4+1$ planlı yazma ve değerlendirme 1 modeli

38. Dikte 1

39. E-posta yazma yeterliliği 1

40. Kurgu merdiveni 1

Yazma becerisi ile ilgili 42 farklı anahtar kelimeye ulaşılmıştır. Tabloya göre yazma becerisi ile ilgili anahtar kelimelerin 'yazma', 'yazma becerisi' ve 'yazma eğitimi' gibi genel kelimeler olduğu söylenebilir.

Konuşma becerisine ilişkin anahtar kelimelere Tablo 4'te yer verilmiştir.

Tablo 4.

Konuşma Becerisine iliş̧kin Anahtar Kelimeler

\begin{tabular}{|c|c|c|c|c|c|}
\hline Sira & Anahtar Kelimeler & $f$ & Sira & Anahtar Kelimeler & $f$ \\
\hline 1. & Konuşma & 5 & 12. & Konuşma sanatı & 1 \\
\hline 2. & Konuşma becerisi & 5 & 13. & Güzel ve etkili konuşma & 1 \\
\hline 3. & Prozodi & 3 & 14. & Sözlü iletişim & 1 \\
\hline 4. & İletişim & 2 & 15. & Hazırlıklı konuşma & 1 \\
\hline 5. & Konuşma eğitimi & 2 & 16. & Hazırlıksız konuşma & 1 \\
\hline 6. & Sesletim & 2 & 17. & Konuşma türleri & 1 \\
\hline 7. & Konuşma dili & 1 & 18. & Konuşma süreci & 1 \\
\hline 8. & Konuşma eğitimi dersi & 1 & 19. & Konuşma öğretimi sorunları & 1 \\
\hline 9. & Etkili iletişim & 1 & 20. & İletişim becerisi değerlendirme & 1 \\
\hline 10. & İletişim becerisi & 1 & 21. & Hikâye anlatma & 1 \\
\hline 11. & İletişim amaçları & 1 & & & \\
\hline
\end{tabular}

Konuşma becerisine ilişkin 21 farklı anahtar kelimeye ulaşılmıştır. Konuşma becerisine yönelik anahtar kelimelerin, yazma ve okuma becerisine ilişkin kelimelere göre daha az olduğu görülmüştür. Tablo 4 incelendiğinde konuşma becerisine ilişkin konuşma ve konuşma becerisi gibi temel sözcüklerden sonra en fazla ele alınan konunun prozodi olduğu söylenebilir.

Dinleme becerisine ilişkin anahtar kelimelere Tablo 5'te yer verilmiştir.

Tablo 5.

Dinleme Becerisine Ilişkin Anahtar Kelimeler

\begin{tabular}{clc|cll}
\hline Sıra & Anahtar Kelimeler & $\mathrm{f}$ & Sıra & Anahtar Kelimeler & $\mathrm{f}$ \\
\hline 1. & Dinleme becerisi & 4 & 6. & Dinleme teknikleri & 1 \\
2. & Dinleme eğitimi & 3 & 7. & Dinlemeye yönelik tutumlar & 1 \\
3. & Etkin dinleme & 2 & 8. & Dinleme/izleme & 1 \\
4. & Dinleme & 2 & 9. & Dinleme stili & 1 \\
5. & Dinleme yöntemleri & 1 & 10. & Dinleme stili ölçeği & 1 \\
\hline
\end{tabular}


Dinleme becerisine ilişkin 10 farklı anahtar kelime tespit edilmiştir. Dinleme becerisine ilişkin çalışmaların anahtar kelime seçiminin, 'dinleme becerisi' ve 'dinleme eğitimi' gibi temel kelimelere odaklandığı görülmektedir. Tablo 5'e göre hem farklı kelime sayısı hem de kelimelerin frekans değerleri dikkate alındığında dinleme eğitimine yönelik anahtar kelimelerin diğer dil becerilerine oranla az olduğu söylenebilir.

Söz varlı̆̆ına ilişkin anahtar kelimeler Tablo 6'da sunulmuştur.

Tablo 6.

Söz Varlığına ilişskin Anahtar Kelimeler

\begin{tabular}{clc|cll}
\hline Sıra & Anahtar kelimeler & $\mathrm{f}$ & Sıra & Anahtar kelimeler & $\mathrm{f}$ \\
\hline 1. & Söz varlığı & 14 & 14. & Kelime farkındalığı & 1 \\
2. & Kelime hazinesi & 8 & 15. & Kelime sayısı & 1 \\
3. & Sözcük öğretimi & 8 & 16. & Atasözleri & 1 \\
4. & Kelime & 4 & 17. & Söz varlığı dizini & 1 \\
5. & Deyim & 3 & 18. & Kelime oluşturma & 1 \\
6. & Kelime hazinesi katsayısı & 2 & 19. & Kelime türetme & 1 \\
7. & Sözlük & 2 & 20. & Kültürel farklılık & 1 \\
8. & Sözlük etkinlikleri & 1 & 21. & Kalıplaşmı̧ sözvarlı̆̆ı \\
9. & Deyim sözlükleri & 1 & 22. & Kelime sıklığı & 1 \\
10. & Deyim öğretimi & 1 & 23. & Sözcük seçimi & 1 \\
11. & Kelime öğretimi çalışmaları & 1 & 24. & Kelime kullanım sıklığı \\
12. & Sözcük edinimi & 1 & 25. & Kelime öğrenme stratejileri & 1 \\
13 & Söz varlığı unsurları & 1 & 26. & Ortak söz varlığı & 1 \\
& Alıntı kelimeler & 1 & & & 1 \\
\hline
\end{tabular}

Söz varlığına ilişkin 26 farklı anahtar kelime kullanılmıştır. Söz varlığı çalışmalarında en çok kullanılan anahtar kelime ise 'söz varlığı' olmuştur. Anahtar kelimelerin frekans değerleri incelendiğinde söz varlığına ilişkin çalışmaların kelime hazinesi ve sözcük öğretimi konularına yoğunlaştığı söylenebilir.

Dil bilgisine ve dilbilime ilişkin anahtar kelimeler Tablo 7'de sunulmuştur.

Tablo 7.

Dil Bilgisi ve Dilbilim Alanına İlişkin Anahtar Kelimeler

\begin{tabular}{|c|c|c|c|c|c|}
\hline Sira & Anahtar Kelimeler & $f$ & Sira & Anahtar Kelimeler & $f$ \\
\hline 1. & Dil bilgisi & 6 & 29. & Belirtme durumu & 1 \\
\hline 2. & Söz dizimi & 4 & 30. & Öbek yapı & 1 \\
\hline 3. & Derlem & 3 & 31. & Dil dışı gösterge & 1 \\
\hline 4. & İsim fiil & 2 & 32. & Eş morfolojik yapılar & 1 \\
\hline 5. & Dil bilgisi öğretimi & 2 & 33. & İsim-fiillerin öğretimi & 1 \\
\hline 6. & Noktalama işaretleri & 2 & 34. & Mastar ekleri & 1 \\
\hline 7. & Noktalama & 1 & 35. & Yaratıcı dil bilgisi etkinlikleri & 1 \\
\hline 8. & Anlatım bozukluğu & 1 & 36. & Altulamlama & 1 \\
\hline 9. & Zaman ekleri & 1 & 37. & Eşdizim & 1 \\
\hline 10. & İşlev & 1 & 38. & Eklemeli dil & 1 \\
\hline 11. & Fiilimsi & 1 & 39. & Yapım eki & 1 \\
\hline 12. & Zarf-fiil & 1 & 40. & Ünlem & 1 \\
\hline 13. & Sifatlar & 1 & 41. & Soru işareti & 1 \\
\hline 14. & Pekiştirme & 1 & 42. & Üç nokta & 1 \\
\hline 15. & İkileme & 1 & 43. & Parçalarüstü sesbilgisi & 1 \\
\hline 16. & Türkiye Türkçesi & 1 & 44. & Parçasal sesbilgisi & 1 \\
\hline 17. & Kalıplaşma & 1 & 45. & Sesbilgisi farkındalığı & 1 \\
\hline
\end{tabular}


18. Tezlik

19. Tarz kalıbı

20. Yansıtıcı sesletim öğretimi

21. Göstergebilim

22. Pop dili

23. İşlevsel dil kullanımı

24. Dil farkındalığı

25. Türkçenin ağızları

26. Anadolu ağızları

27. Duygu bildiren dil unsurları

28. Dil etkinlikleri
46. Dilbilgisine yönelik tutum ölçeği 1

47. Parçacıl/parçaüstü fonoloji 1

48. Psikodilbilim 1

49. Beyindilbilim 1

50. Kalıplaşmış dil 1

51. Eskicil yapı 1

52. Dilsel kullanımlar 1

53. Ses sıklığı 1

54. Harf sıklığı 1

55. Dil yanlışları 1

Dil bilgisi ve dilbilim alanına yönelik 56 farklı anahtar kelime tespit edilmiştir. Tablo 7’ye göre 'dil bilgisi' ve 'söz dizimi' en sık kullanılan anahtar kelimelerdir. Dil bilgisine yönelik farklı anahtar kelime sayısı fazla olsa da kelimelerin frekans değerleri çoğunlukla 1'dir.

Tablo 8.

Öğretmen/Öğretmen Adayı/Öğrenci/Ebeveyn Kavram Alanına Ilişkin Anahtar Kelimeler

\begin{tabular}{|c|c|c|c|c|c|}
\hline Sira & Anahtar kelimeler & $f$ & Sira & Anahtar kelimeler & $f$ \\
\hline 1. & $\begin{array}{l}\text { Türkçe öğretmeni adayları/adayı-Türkçe } \\
\text { öğretmen adayı/adayları }\end{array}$ & 10 & 22. & Suriyeli öğrenciler & 1 \\
\hline 2. & Sınıf öğretmeni/öğretmenleri & 6 & 23. & Yabancı öğrenciler & 1 \\
\hline 3. & Öğretmen/Öğretmenler & 6 & 24. & ilkokul öğrencileri & 1 \\
\hline 4. & Öğretmen adayı & 4 & 25. & İlkokul birinci sınıf & 1 \\
\hline 5. & Öğrenci/öğrenciler & 4 & 26. & Öğretmen öz yeterliliği & 1 \\
\hline 6. & Öğretmen görüşleri & 4 & 27. & Öğretmenlik algısı & 1 \\
\hline 7. & Öğretmen yetiştirme & 4 & 28. & Öğretmenlik uygulaması & 1 \\
\hline 8. & Öğretmen adayları & 3 & 29. & Pedagojik formasyon & 1 \\
\hline 9. & Öğrenci görüşleri & 2 & 30. & Sınıf öğretmeni adayı & 1 \\
\hline 10. & Öğretmen eğitimi & 2 & 31. & Öğretmen yeterlilikleri & 1 \\
\hline 11. & Yetişkin & 2 & 32. & Ortaokul öğrencileri & 1 \\
\hline 12. & İki dilli öğretmen & 1 & 33. & Ortaokul 6. Sınıf öğrencileri & 1 \\
\hline 13. & Dördüncü sınıf öğrencileri & 1 & 34. & $\begin{array}{l}\text { Türkçe ve Türk kültürü } \\
\text { öğretmeni }\end{array}$ & 1 \\
\hline 14. & 9. Sınıf öğrencileri & 1 & 35. & Pedagojik alan bilgisi & 1 \\
\hline 15. & Altıncı sınıf öğrencileri & 1 & 36. & Dramatik ana-baba tutumu & 1 \\
\hline 16. & Okul öncesi öğretmen & 1 & 37. & Otoriter ana-baba tutumu & 1 \\
\hline 17. & Üniversite öğrencileri & 1 & 38. & Baba otoritesi & 1 \\
\hline 18. & 8. Sınıf öğrencileri & 1 & 39. & Pedagoji tarihi & 1 \\
\hline 19. & Öğretmen rolü & 1 & 40. & Veli & 1 \\
\hline 20. & Eleştirel pedagoji & 1 & 41. & Veli görüşleri & 1 \\
\hline 21. & 6, 7 ve 8. sınıf öğrencileri & 1 & & & \\
\hline
\end{tabular}

Tablo 8 incelendiğinde öğretmen, öğretmen adayı, öğrenci ve ebeveynlerle ilgili 47 farklı anahtar kelimeye yer verildiği görülmektedir. En çok kullanılan anahtar kelime/kelime grubu ise Türkçe öğretmeni adaylarına yönelik kelimelerdir.

Türkçe eğitimi-öğretimi ders kitaplarına ilişkin anahtar kelimeler Tablo 9'da sunulmuştur. 
Tablo 9.

Ders Kitaplarına ilişskin Anahtar Kelimeler

\begin{tabular}{|c|c|c|c|c|}
\hline Sira & Anahtar kelimeler & $f$ & Sira & Anahtar kelimeler \\
\hline 1. & Türkçe ders kitapları/kitabı & 18 & 8. & Türkçe dersi kitapları \\
\hline 2. & Ders kitabı/kitapları & 7 & 9. & $\begin{array}{l}\text { Türkçe ders ve öğrenci çalışma } \\
\text { kitabı }\end{array}$ \\
\hline 3. & Öğrenci çalışma kitapları & 2 & 10. & $\begin{array}{l}\text { Yabancılara Türkçe öğretimi } \\
\text { ders kitapları }\end{array}$ \\
\hline 4. & Öğretmen kılavuz kitabı & 2 & 11. & Ders kitabı inceleme \\
\hline 5. & 8. Sınıf Türkçe ders kitabı & 1 & 12. & 5. sınıf Türkçe ders kitabı \\
\hline 6. & Türkçe dersi öğretmen kılavuz kitabı & 1 & 13. & Yedi iklim Türkçe seti \\
\hline 7. & Yabancı dil Türkçe kitapları & 1 & & \\
\hline
\end{tabular}

Tabloya göre ders kitaplarına yönelik 15 farklı anahtar kelime kullanılmıştır. En çok kullanılan anahtar kelime ise Türkçe ders kitaplarına ilişkin kelimelerdir.

Metin ve metin çözümlemeye ilişkin anahtar kelimelere Tablo 10'da yer verilmiştir.

Tablo 10.

Metin ve Metin Çözümleme Kavram Alanına Illişkin Anahtar Kelimeler

\begin{tabular}{|c|c|c|c|c|c|}
\hline Sira & Anahtar kelimeler & $\mathrm{f}$ & Sira & Anahtar kelimler & $f$ \\
\hline 1. & Metin & 10 & 30. & Metin hazırlama & 1 \\
\hline 2. & Metin türü/metin türleri & 4 & 31. & Metin resimleme & 1 \\
\hline 3. & Masal & 5 & 32. & Edebi metinler & 1 \\
\hline 4. & Şiir & 4 & 33. & Metindilbilim & 1 \\
\hline 5. & Edebiyat & 3 & 34. & Tiyatro metni & 1 \\
\hline 6. & Roman & 2 & 35. & Metin çözümleme & 1 \\
\hline 7. & Türkü & 2 & 36. & Metin konusu & 1 \\
\hline 8. & Hikâye/öykü & 5 & 37. & Metin içeriği & 1 \\
\hline 9. & Metin yapısı & 3 & 38. & Metin anlamlandırma & 1 \\
\hline 10. & Metin işleme süreci & 2 & 39. & Öykü metinleri & 1 \\
\hline 11. & Tartışmacı metin & 2 & 40. & Tür & 1 \\
\hline 12. & Metinsellik ölçütleri & 2 & 41. & Başlık & 1 \\
\hline 13. & Öyküleyici metin & 2 & 42. & Fabl & 1 \\
\hline 14. & Eğitici metinler & 1 & 43. & Hayvan karakterler & 1 \\
\hline 15. & Metin seçimi & 1 & 44. & Korku öyküleri & 1 \\
\hline 16. & Metni anlama & 1 & 45. & Çizgi roman & 1 \\
\hline 17. & Metin antolojisi & 1 & 46. & Film & 1 \\
\hline 18. & Kurmaca metin & 1 & 47. & Türk masalları & 1 \\
\hline 19. & Metin kavrama & 1 & 48. & Destan & 1 \\
\hline 20. & Metinden öğrenme & 1 & 49. & Öykü unsurları & 1 \\
\hline 21. & Haber metinleri & 1 & 50. & Dijital öykü & 1 \\
\hline 22. & Metinlerarasılık & 1 & 51. & Eleştirel söylem çözümlemesi & 1 \\
\hline 23. & Derin yapı & 1 & 52. & Söylem çözümlemesi & 1 \\
\hline 24. & Yüzey yapı & 1 & 53. & Mizah & 1 \\
\hline 25. & Üstyapı & 1 & 54. & Türk romanı & 1 \\
\hline 26. & Metin kullanımı & 1 & 55. & Yunan masalları & 1 \\
\hline 27. & Tutarlılık ve bağdaşıklık & 1 & 56. & Çeviri eser & 1 \\
\hline 28. & Bağdaşıklık & 1 & 57. & Okur-tepki kuramı & 1 \\
\hline 29. & Kaynak metin & 1 & & & \\
\hline
\end{tabular}


Tablo 10' göre metin kavram alanına ilişkin 59 farklı anahtar kelime kullanılmıştır. En çok kullanılan anahtar kelime 'metin' ve 'metin türleri' kelimeleridir. Tablo incelendiğinde Ana Dili Eğitimi dergisinde metin kavram alanı ile ilgili çok sayıda makalenin yer aldığı söylenebilir.

Değer ve değer eğitimine ilişkin anahtar kelimeler Tablo 11'de sunulmuştur.

Tablo 11.

Değer ve Değer Eğitimine ilişkin Anahtar Kelimeler

\begin{tabular}{clc|cll}
\hline Sıra & Anahtar kelimeler & $\mathrm{f}$ & Sıra & Anahtar kelimler & $\mathrm{f}$ \\
\hline 1. & Değerler/değer & 7 & 9. & Değerler eğitimi & 2 \\
2. & Ileti & 4 & 10. & Değerler öğretimi & 1 \\
3. & Metafor & 3 & 11. & Milli değer & 1 \\
4. & Eğitsel ileti & 3 & 12. & Manevi değer & 1 \\
5. & Karakter & 2 & 13. & Evrensel değer & 1 \\
6. & Karakter eğitimi & 2 & 14. & Eğitsel değer & 1 \\
7. & Schwartz değer ölçeği/listesi & 2 & 15. & Kök değerler & 1 \\
8. & Karakter özellikleri & 2 & 16 & Değerler iletimi & 1 \\
\hline
\end{tabular}

Tablo 11'e göre değer/değer eğitimine yönelik 17 farklı anahtar kelime kullanılmıştır. En çok kullanılan anahtar kelimeler ise 'değer/değerler' kelimeleridir.

Çocuk/çocuk edebiyatına ilişkin anahtar kelimelere Tablo 12' de yer verilmiştir.

Tablo 12.

Çocuk/Çocuk Edebiyatına iliş̧in Anahtar Kelimeler

\begin{tabular}{clllll}
\hline Sıra & Anahtar kelime & $\mathrm{f}$ & Sıra & Anahtar kelime & $\mathrm{f}$ \\
\hline 1. & Çocuk edebiyatı & 10 & 14. & Gençlik edebiyatı & 1 \\
2. & Çocuk kitapları & 2 & 15. & Çocuk edebiyatında karakter & 1 \\
3. & Çocuk tiyatrosu & 2 & 16. & Çocuk hikâyeleri & 1 \\
4. & Çizgi film & 2 & 17. & Kurgusal çocuk edebiyatı & 1 \\
5. Çeviri çocuk kitapları & 1 & 18. & Çocuk romanı & 1 \\
6. Çocuk şiiri & 1 & 19. & Çocuk dili derlemi & 1 \\
7. Çocuk ve gençlik yazını & 1 & 20. & Çocuğa görelik & 1 \\
8. Çocuk dergisi & 1 & 21. & Çocuk gerçekliği & 1 \\
9. Türk çocuk edebiyatı & 1 & 22. & Resimli çocuk kitapları & 1 \\
10. Çocuk öyküsü & 1 & 23. & Keloğlan masalı & 1 \\
11. Disney Cahannel & 1 & 24. & Oyun & 1 \\
12. Cartoon Network & 1 & 25. & Televizyon ve çocuk & 1 \\
13. Çocuk oyunları & 1 & 26. & Melezleşen oyunlar & 1 \\
\hline
\end{tabular}

Tablo 12'ye göre çocuk ve çocuk edebiyatı alanına ilişkin 26 farklı anahtar kelime kullanılmıştır. En çok kullanılan anahtar kelime ise 'çocuk edebiyatı'dır.

Drama ve tiyatroya ilişkin anahtar kelimeler Tablo 13'te sunulmuştur.

Tablo 13.

Drama ve Tiyatroya ilişkin Anahtar Kelimeler

\begin{tabular}{clc}
\hline Sıra & Anahtar kelimeler & $f$ \\
\hline 1. & Yaratıcı drama & 6 \\
2. & Drama & 5 \\
3. & Tiyatro & 2 \\
4. & Dramatizasyon & 1 \\
5. & Tiyatro ve drama uygulamaları & 1 \\
\hline
\end{tabular}


Tablo 13 incelendiğinde drama ve tiyatro alanına ilişkin 5 farklı anahtar kelime kullanıldığı görülmektedir. En çok kullanılan anahtar kelime ise 'yaratıcı drama'dır.

Türkçe eğitimi-öğretimi/yabancılara Türkçe öğretimi/dil öğretimi alanlarına ilişkin anahtar kelimelere Tablo 14'te sunulmuştur. Bu alanlarla ilgili frekans değeri 1 olan kelime sayısının fazla olması nedeniyle tabloya frekans değeri 2 ve üzeri olan kelimeler alınmıştır.

Tablo 14.

Türkçe Eğitimi-Öğretimi/Yabancılara Türkçe Öğretimi/Dil Öğretimi Alanlarına iliş̧kin Anahtar Kelimeler

\begin{tabular}{|c|c|c|c|c|c|}
\hline Sira & Anahtar kelimeler & $f$ & Sira & Anahtar kelimeler & $f$ \\
\hline 1. & Türkçe eğitimi & 34 & 35. & Eğitim teknolojisi & 3 \\
\hline 2. & Türkçe öğretimi & 32 & 36. & Dil eğitimi & 2 \\
\hline 3. & Yabancı dil olarak Türkçe öğretimi & 16 & 37. & Dil edinimi & 2 \\
\hline 4. & Yabancılara Türkçe öğretimi & 11 & 38. & Dil gelişimi & 2 \\
\hline 5. & Tutum & 12 & 39. & Illköğretim & 2 \\
\hline 6. & Türkçe dersi & 9 & 40 & TEOG & 2 \\
\hline 7. & Türkçe dersi öğretim programı & 9 & 41. & Etkinlik yaklaşımı & 2 \\
\hline 8. & Türkçe & 9 & 42. & Motivasyon & 2 \\
\hline 9. & illkokul & 8 & 43. & Milli eğitim bakanlığı/MEB & 2 \\
\hline 10. & Ana dili & 7 & 44. & Öz yeterlik algısı & 2 \\
\hline 11. & Kültür & 7 & 45. & Web 2.0 araçları & 2 \\
\hline 12. & Dil becerileri & 7 & 46. & Web 2.0 & 2 \\
\hline 13. & Etkinlik & 7 & 47. & Yaratıcılık & 2 \\
\hline 14. & İki dillilik & 6 & 48. & Vosviewer & 2 \\
\hline 15. & Ölçme değerlendirme & 5 & 49. & Görüş/görüşler & 2 \\
\hline 16. & Öğretim programı & 5 & 50. & Okul öncesi dönem & 2 \\
\hline 17. & Kazanım & 5 & 51. & Tez & 2 \\
\hline 18. & Ortaokul & 5 & 52. & İnceleme & 2 \\
\hline 19. & Türkçe öğretim programları/programı & 4 & 53. & Nicel araştırma/nicel çalışma & 2 \\
\hline 20. & Yanlış çözümleme/hata analizi & 4 & 54. & Nitel araştırma & 2 \\
\hline 21. & Türkçenin yabancı dil olarak öğretimi & 4 & 55. & Eylem araştırması & 2 \\
\hline 22. & İçerik analizi & 4 & 56. & Geçerlik & 2 \\
\hline 23. & Tema/temalar & 4 & 57. & Güvenirlik & 2 \\
\hline 24. & Ana dili eğitimi & 4 & 58. & Hedef & 2 \\
\hline 25. & Temel beceriler & 4 & 59. & Algı & 2 \\
\hline 26. & Değerlendirme & 4 & 60. & Bilgi türleri & 2 \\
\hline 27. & Program & 4 & 61. & Teknoloji & 2 \\
\hline 28. & Dil & 3 & 62. & Birleştirilmiş sınıf & 2 \\
\hline 29. & Dil öğretimi & 3 & 63. & Temel eğitim & 2 \\
\hline 30. & Ölçek geliştirme & 3 & 64. & $\begin{array}{l}\text { Yurt dışındaki Türk } \\
\text { çocuklarına Türkçe öğretimi }\end{array}$ & 2 \\
\hline 31. & Eleştirel düşünme/düşünce & 3 & 65. & Yabancı dil olarak Türkçe & 2 \\
\hline 32. & Tutum ölçeği & 3 & 66. & Türkçe ve Türk kültürü dersi & 2 \\
\hline 33. & Aktif öğrenme & 3 & 67. & Kültür aktarımı & 2 \\
\hline 34. & Özyeterlik & 3 & & & \\
\hline
\end{tabular}

Tablo 14'e göre Türkçe eğitimi-öğretimi/yabancılara Türkçe öğretimi/dil öğretimi alanlarına ilişkin frekans değeri 2 ve üzerinde olan 74 farklı anahtar kelime kullanılmıştır. En çok kullanılan anahtar kelimeler ise 'Türkçe eğitimi' ve 'Türkçe öğretimi'dir. Tabloların tamamı dikkate alındığında dergide yer alan makalelerin çoğunlukla Türkçe eğitimi-öğretimi ile ilişkili olduğu söylenebilir. 


\section{Tartışma ve Sonuç}

Ana Dili Eğitimi Dergisi'nde 2013-2020 yılları arasında yayınlanan 335 makalenin anahtar kelimelerinin incelendiği bu çalışmada, dergide yayınlanan makalelerin Türkçe eğitimi ile doğrudan ve dolaylı olarak ilgili olduğu görülmüştür.

Temel dil becerilerine ilişkin anahtar kelimelerin belirli alanlarda yoğunlaştığı sonucuna ulaşılmıştır. Okuma becerisi ile ilgili 49, yazma becerisi ile ilgili 42 farklı anahtar kelimenin kullanıldığı tespit edilirken konuşma becerisi ile ilgili 21, dinleme becerisi ile ilgili ise 10 farklı anahtar kelime kullanıldığı tespit edilmiştir. Dolayısıyla dergide yayınlanan ve temel dil becerilerini konu alan makalelerin çoğunlukla okuma ve yazma becerileri ile ilgili olduğu söylenebilir. Karagöz ve Koç-Ardıç (2018) Ana Dili Eğitimi Dergisi'nde temel dil becerilerine eşit derecede önem verilmediğini, dinleme ve konuşma becerilerine yönelik çalışmaların okuma ve yazma becerilerine oranla az olduğunu ifade etmişlerdir. Ana Dili Eğitimi Dergisi'nde yayınlanan makaleleri inceleyen Mutlu (2018) da temel dil becerileri ile ilgili çalışmaların okuma ve yazma alanında yoğunlaştığına, konuşma ve dinleme alanına yönelik çalışmaların ise azlığına dikkat çekmiştir. Lisansüstü tezleri inceleyen Sevim ve İşcan (2012) aynı sonuca ulaşmışlardır. Yabancılara Türkçe öğretimi alanında yayınlanan tez ve makaleleri inceleyen Büyükikiz (2014) ve Erdem ve ark. (2015) dinleme ve konuşma becerisine yönelik çalışmaların az olduğu sonucuna ulaşmışlardır. Bu bağlamda Türkçe eğitimi-öğretimi alanında dinleme ve konuşma becerilerinin az tercih edilen araştırma konuları olduğu söylenebilir. Alan yazında konuşma ve dinleme becerilerine yönelik çalışmaların azlığına, bu becerilere yönelik etkinlik hazırlamanın, veri toplamanın ve ölçme-değerlendirme yapmanın zorluğu neden olarak gösterilmiştir.

Temel dil becerilerinden okuma ve yazma becerileri ile ilgili anahtar kelimelere bakıldığında okuma becerisine yönelik en sık kullanılan anahtar kelimenin 'okuma', 'okuduğunu anlama' ve 'ilk okuma yazma', yazma becerisine yönelik ise 'yazılı anlatım', 'yaratıcı yazma' ve 'akademik yazma' olduğu görülmektedir. Alan yazında bu durumu destekleyen sonuçlar bulunmaktadır. Akaydın ve Çeçen (2015), okuma alanına ilişkin makalelerin 'okuduğunu anlama' konularında yoğunlaştığını ifade etmişlerdir. Karagöz ve Şeref (2019a) okuma alanındaki araştırmaları bibliyometrik özellikler açısından inceledikleri çalışmalarında, okuma alanı ile ilgili en çok 'okuma' ve 'okuma anlama' anahtar kelimelerinin kullanıldığını tespit etmişleridir. Aynı şekilde yazma alanına yönelik çalışmaları inceleyen Karagöz ve Şeref (2020), yazma alanı ile ilgili en çok 'akademik yazma' anahtar kelimesinin kullanıldığı sonucuna ulaşmışlardır.

Söz varlığına ilişkin anahtar kelimeler incelendiğinde çoğunlukla söz varlığı ile ilgili genel kavramlara yer verildiği görülmektedir. En çok kullanılan kelimeler 'söz varlığı', 'kelime hazinesi' ve 'sözcük öğretimi'dir. Söz varlığına en çok kullanılan anahtar kelimeler ise 'kelime' ve 'deyim'dir. Sevim ve İşcan (2012) ve Büyükikiz (2014) söz varlığıyla ilgili çalışmalarda 'kelime', 'atasözü' ve 'deyim' öğretimine yönelik kelimelerin çok kullanıldığını belirtmişlerdir.

Incelenen makalelerde dil bilgisi ve dilbilime yönelik anahtar kelimelerin sıkılıkla kullanıldığı sonucuna ulaşılmıştır. En sık kullanılan anahtar kelimeler 'dil bilgisi', 'derlem' ve 'söz dizimi'dir. Mutlu (2018), Ana Dili Eğitimi Dergisi'ndeki makalelerin en çok dil bilgisi ve dil araştırmaları ile ilgili olduğunu ifade etmiştir. Sevim ve İşcan (2012) Türkçe eğitimi ile ilgili lisansüstü tezlerde dil, dil bilgisi ve dil bilgisi öğretimine yönelik anahtar kelimelerin sayıca fazla olduğu sonucuna ulaşmışlardır. Karagöz ve KoçArdıç (2018) da Ana Dili Eğitimi Dergisi'nde en çok çalışılan konulardan birinin dil bilgisi ve dil araştırmaları olduğunu belirtmişlerdir. Son yıllarda araştırmacılar tarafından ilgi gören derlem konusundaki anahtar kelimelerin kullanım sıklığı da dikkat çekici bir sonuçtur.

Öğretmen, öğretmen adayı, öğrenci ve ebeveyn teması altında çok sayıda anahtar kelimenin kullanıldığı görülmektedir. Bu tema altında en çok kullanılan anahtar kelimeler 'Türkçe öğretmeni adayı', 'sınıf öğretmeni' ve genel olarak 'öğretmen' kelimeleridir. Türkçe eğitiminde öğretmen ve öğretmen adaylarının görüşlerine başvuran çok sayıda çalışmanın varlığının Ana Dili Eğitimi Dergisi'ndeki çalışmaları da etkilediği söylenebilir. Ders kitaplarına ilişkin en çok kullanılan anahtar kelimeler ise 'Türkçe ders kitapları' ve 'ders kitabı'dır. Mutlu (2018), Ana Dili Eğitimi Dergisi'nde ders kitapları ile ilgili çok sayıda çalışma olduğundan bahsetmiştir.

Metin, metin türleri ve metin çözümlemeye ilişkin anahtar kelime sayısının fazlalığı dikkat çeken bir sonuçtur. Bahsedilen tema ile ilgili olarak en sık kullanılan anahtar kelime 'metin', 'masal' ve 
'metin türü’dür. Karagöz ve Koç Ardıç (2018) Ana Dili Eğitimi Dergisi'nde metin türlerinin ve metin incelemenin en sık ele alınan ikinci konu olduğunu ifade etmişlerdir.

Değerler eğitimi ile ilgili en sık kullanılan anahtar kelime 'değer/değerler' kelimeleridir. Karagöz ve Şeref (2019b) Değerler Eğitimi Dergisi'nin bibliyometrik görünümünü ortaya koydukları çalışmalarında dergideki makalelerin değer eğitimi konusunda yoğunlaştı̆̆ını ve en sık kullanılan anahtar kelimenin ise 'değerler' ve 'din eğitimi' olduğunu tespit etmişlerdir. Ana Dili Eğitimi Dergisi'nde ise değerlerin eğitim ortamındaki işlevi ve kitaplardaki değerlerin tespit edilmesine yönelik anahtar kelimelerin kullanıldığı görülmektedir.

Çocuk edebiyatına yönelik anahtar kelimeler sayıca fazla görünse de kelimelerin frekans değerlerinin çoğunlukla 1 olduğu sonucuna ulaşılmıştır. En çok kullanılan anahtar kelime 'çocuk edebiyatı'dır. Sevim ve İşcan (2012) çocuk edebiyatı alanında yapılan tezlerde en çok çocuğa görelik ilkesine yönelik anahtar kelimelerin kullanıldığını tespit etmişlerdir. Mutlu (2018) Ana Dili Eğitimi dergisinde en az çalışılan konulardan birinin çocuk edebiyatı olduğunu belirtmiştir. Varışoğlu ve ark. (2012), çocuk edebiyatı alanında az çalışmanın olduğunu ifade etmiş ve bunu doçentlik alanı olarak Türkiye' de böyle bir alanın olmaması ile ilişkilendirmiştir.

Drama ve tiyatroya ilişkin anahtar kelimelerin sayısal az ve frekans değerleri bakımından da düşük olduğu sonucuna ulaşılmıştır. En çok kullanılan anahtar kelimeler 'drama' ve 'yaratıcı drama'dır. Bu durumda Ana Dili Eğitimi Dergisi'nde, drama ve tiyatronun Türkçe eğitimi ile ilişkilendirildiği çalışmaların az olduğu söylenebilir.

Türkçe eğitimi-öğretimi, yabancılara Türkçe öğretimi ve dil öğretimi alanlarına ilişkin farklı anahtar kelime sayısının çok fazla olması nedeniyle frekans değeri 2 ve üzerinde olan kelimeler incelemeye dâhil edilmiştir. Bu tema altında en çok kullanılan kelimeler 'Türkçe eğitimi', 'Türkçe öğretimi', 'Yabancı dil olarak Türkçe öğretimi' ve 'Yabancılara Türkçe öğretimi'dir. Karagöz ve Koç Ardıçın (2018) belirttiği gibi Ana Dili Eğitimi Dergisinin Türkçe eğitimi akademik alanında ilk bilimsel dergi olması en çok kullanılan anahtar kelimelerin de Türkçe eğitimi-öğretimi ile ilişkili olması beklenen bir sonuçtur. Yabancılara Türkçe öğretimine ilişkin anahtar kelimeler incelendiğinde 'Yabancı dil olarak Türkçe öğretimi', 'Yabancılara Türkçe öğretimi' ve 'Türkçenin yabancı dil olarak öğretimi' kelimeler tespit edilmiştir. Bu bağlamda alanla ilgili bir terim sorunu yaşandığı söylenebilir.

\section{Kaynaklar}

Akaydın, Ş. ve Çeçen, M. A. (2015). Okuma becerisiyle ilgili makaleler üzerine bir içerik analizi. Eğitim ve Bilim, 40(178), 183-198.

Aktaş, E. ve Uzuner Yurt, S. (2015). Türkçe eğitimi alanındaki makale özetlerine yönelik bir içerik analizi. Turkish Studies, 10(7), 73-96.

Alver, M. ve Taşdemir, L. (2017). Konuşma becerisi üzerine yapılan lisansüstü tezlerin incelenmesi. International Journal of Languages' Education and Teaching, 5(3), 451-462.

Balcı, A., Coşkun, E. ve Özçakmak, H. (2013). Trends in reading education: An analysis of postgraduate theses written in Turkey. Procedia - Social and Behavioral Sciences, 93, 1574-1579.

Bozkurt, B. ve Uzun, N. E. (2015). Türkçenin eğitimi-öğretimine ilişkin bir alanyazını değerlendirmesi: uluslararası bilimsel toplantılarda eğilimler/yönelimler. Dil Eğitimi ve Araştırmaları Dergisi, 1(2), 1-15.

Boyacı, S. ve Demirkol, S. (2018). Türkçe eğitimi alanında yapılan doktora tezlerinin incelenmesi. Ana Dili Eğitimi Dergisi, 6(2), 512-531.

Büyükikiz, K. (2014). Yabancılara Türkçe öğretimi alanında hazırlanan lisansüstü tezler üzerine bir Inceleme. Mustafa Kemal Üniversitesi Sosyal Bilimler Enstitüsü Dergisi, 11(25), 203-213.

Ceren, D., Aydın, M. ve Onarıcıoğlu, A. S. (2018). Okuma eğitimi üzerine yapılan tezlerde eğilimler: bir içerik analizi çalışması. Ahi Evran Üniversitesi Kırşehir Eğitim Fakültesi Dergisi, 19(3), 23772392.

Coşkun, E., Balcı, A. ve Özçakmak, H. (2013). Trends in writing education: An analysis of postgraduate theses written in Turkey. Procedia - Social and Behavioral Sciences, 93, 1526-1530.

Dilidüzgün, Ş. (2017). Metindilbilim ve Türkçe öğretimi. Ankara: Anı Yayınları. 
Doğan, Y. ve Özçakmak, H. (2014). Dinleme becerisinin eğitimi üzerine yapılan lisansüstü tezlerin değerlendirilmesi. Ana Dili Eğitimi Dergisi, 2(2), 90-99.

Elbir, B. ve Yıldız, H. (2012). İlköğretim yazma eğitimi üzerine yapılan lisansüstü çalışmalarının değerlendirilmesi. Akademik Bakış Dergisi, 30, 1-11.

Erdem, M. D., Gün, M., Şengül, M. ve Özkan, E. (2015). Yabancı dil olarak Türkçe öğretimi alanında yazılmış bilimsel makalelerde geçen anahtar sözcüklere ilişkin bir içerik analizi. Ondokuz Mayıs Üniversitesi Eğitim Fakültesi Dergisi, 34(1), 213-237.

Karadağ, R. (2014). Okuma ilgisi, tutumları ve alışkanlığı konusunda yapılmış çalışmaların lisansüstü tezlere dayalı analizi: YÖK ve ProQuest veri tabanları örneklemi. Pamukkale Üniversitesi Eğitim Fakültesi Dergisi, 35, 1-17.

Karagöz, B. ve Koç Ardıç, İ. (2019). Ana dili eğitimi dergisinde yayımlanan makalelerin bibliyometrik analizi. Ana Dili Eğitimi Dergisi, 7(2), 419-435.

Karagöz, B. ve Şeref, i. (2019a). Okuma alanındaki araştırmaların bibliyometrik özellikler açısından incelenmesi. Ana Dili Eğitimi Dergisi, 7(3), 781-799.

Karagöz, B. ve Şeref, i. (2019b). Değerler Eğitimi Dergisi'nin bibliyometrik profili (2009-2018). Değerler Eğitimi Dergisi, 17(37), 219-246.

Karagöz, B. ve Şeref, i. (2020) Yazma becerisiyle ilgili makaleler üzerine bir inceleme: web of Science veri tabanında eğilimler. Ana Dili Eğitimi Dergisi, 8(1), 67-86.

Kardaş, M. N., Çetinkaya, V. ve Kaya, M. (2018). 2005-2017 yılları arasında dinleme eğitimi üzerine yapılmış akademik çalışmaların eğilimleri üzerine bir araştırma. Kuram ve Uygulamada Sosyal Bilimler Dergisi, 2(1), 21-32.

Kemiksiz, Ö. (2017). Dinleme becerisi üzerine yazılan makalelerin değerlendirilmesi. International Journal of Languages' Education and Teaching, 5(1), 511-531.

Merriam, S. B. (2013). Nitel araştırma desen ve uygulama için bir rehber. (Çev. Ed. Selahattin Turan).Ankara: Nobel Yayınları.

Mutlu, H. H. (2018). Ana dili eğitimi dergisinde yayınlanan araştırmaların eğilimleri: İçerik analizi. Ana Dili Eğitimi Dergisi, 6(4), 1196-1209.

Özdemir, S. (2018). Okumaya ilişkin lisansüstü araştırmaların eğilimleri. Ana Dili Eğitimi Dergisi, 6(4), 1161-1178.

Sevim, O. ve İşcan, A. (2012). Türkçenin eğitimi ve öğretimi alanında yapılan yüksek lisans tezlerinde geçen anahtar kelimelere dönük bir içerik analizi. Turkish Studies, 7(1), 1863-1873.

Şeref, i. ve Karagöz, B. (2019). Türkçe eğitimi akademik alanına ilişkin bir değerlendirme: web of science veri tabanına dayalı bibliyometrik inceleme. Dil Eğitimi ve Araştırmaları Dergisi, 5(2), 213-231.

Tatar, E. ve Tatar, E. (2008). Fen bilimleri ve matematik eğitimi araştırmalarının analizi-1: anahtar kelimeler. Inönü Üniversitesi Eğitim Fakültesi Dergisi, 9(16), 89-103.

Tok, M. ve Potur, Ö. (2015). Yazma eğitimi alanında yapılan akademik çalışmaların eğilimleri (20102014 Yılları). Ana Dili Eğitimi Dergisi, 3(4), 1-25.

Uyar, Y. (2016). Yazma becerisini geliştirmeye yönelik araştırmalar: son çeyrek asrın değerlendirilmesi. Turkish Studies, 11, 2273-2294.

Varışoğlu, B.; Şahin, A. ve Göktaş, Y. (2013). Türkçe eğitimi araştırmalarında eğilimler. Kuram ve Uygulamada Eğitim Bilimleri, 13(3), 1767-1781.

Yağmur-Şahin, E., Kana, F. ve Varışoğlu, B. (2013). Türkçe eğitimi bölümlerinde yapılan lisansüstü tezlerin araştırma eğilimleri. International Journal of Human Sciences, 10(2), 356-378.

Yıldırım, A. \& Şimşek, H. (2008). Sosyal bilimlerde nitel araştırma yöntemleri. Ankara: Seçkin Yayıncılık.

\section{Introduction}

\section{Extended Abstract}

In recent years, it is observed that there has been an increase in the number of universities providing postgraduate education in the field of Turkish language education. This increase has also led to an increase in academic studies in the field of Turkish language education. Therefore, it has become highly important to follow under which sub-topics the scientific publications such as articles and theses 
published for researchers studying in the field of Turkish language education-teaching have been concentrated.

One of the most important components of a research is determining the problem to be discussed in the research. In this regard, people who want to do research on a subject need a literature review for purposes such as identifying the topics they want to work on, limiting the subject, and revealing its importance in the literature. In the first stage, the researchers who perform literature review read certain parts of the studies they have reviewed and decide whether they are related to their research. One of the sections that provide information about the content of the studies reviewed is keywords.

\section{Method}

The qualitative basic pattern was preferred in the study. The data were collected using the document analysis method. The data collected by the document analysis method was analyzed by descriptive analysis technique. In the study, the keywords were first identified. Then, the keywords were classified according to the sub-themes associated with the field of Turkish language education and their frequency values were determined. Similar keywords were discussed together and their frequency values are combined. The keywords that were out of the themes determined and had a frequency value of 1 in the Turkish language education-training/Teaching Turkish language to foreigners/language teaching theme are presented as an attached file in the appendix of the article.

The keywords that were determined by the researcher and classified by content analysis method in order to ensure the validity and reliability of the research were presented to the opinions of a domain expert. In accordance with the opinions of the domain expert, some keywords were added to the themes determined.

\section{Result and Discussion}

In this study in which the keywords of 335 articles published in the Journal of Mother Tongue Education between the years 2013 and 2020 were examined, it was observed that the articles published in the journal were directly and indirectly related to Turkish language education.

It was concluded that the keywords related to basic language skills were concentrated in certain areas. It was determined that 49 different keywords related to reading skills and 42 different keywords related to writing skills were used, while 21 different keywords related to speaking skills and 10 different keywords related to speaking skill were used. Therefore, it can be said that the articles published in the journal that discussed basic language skills were mostly related to reading and writing skills.

When the keywords related to vocabulary were analyzed, it was observed that general concepts related to vocabulary were mostly included. The most frequently used words were 'vocabulary', 'thesaurus' and 'word teaching'.

It was concluded that the keywords related to grammar and linguistics were used frequently in the articles analyzed. The most frequently used keywords were 'grammar', 'review' and 'syntax'. Mutlu (2018) indicated that the articles in the Journal of Mother Tongue Education were mostly related to grammar and language research.

It was observed that many keywords were used under the theme of teacher, pre-service teacher, student, and parent. The most frequently used keywords under this theme were 'pre-service Turkish language teacher', 'classroom teacher' and 'teacher' in general. It can be said that the presence of many studies referring to the opinions of teachers and pre-service teachers in Turkish language education also affected the studies in the Journal of Mother Tongue Education.

The high number of keywords related to text, text types and text analysis was a remarkable result. The most frequently used keywords related to this theme were 'text', 'fairy tale' and 'text type'. The most frequently used keywords related to values education were 'value/values'. Although the keywords for children's literature seemed high in number, it was concluded that the frequency values of the words were mostly 1 . The most frequently used keyword was 'children's literature'. 
It was concluded that the keywords related to drama and theater were few in number and low in terms of frequency values. The most frequently used keywords were 'drama' and 'creative drama'.

Since the number of different keywords related to the fields of Turkish language educationtraining, Teaching Turkish language to foreigners and language teaching was very high, the words with a frequency value of 2 and above were included in the analysis. The most frequently used words under this theme were 'Turkish language education', 'Turkish language teaching', 'Teaching Turkish language as a foreign language' and 'Teaching Turkish language to foreigners'. 